\title{
The Razing Tide of the Port of New Orleans: Power, IdeOlogy, ECONOMIC Growth AND the Destruction of COMMUNITY
}

\author{
BRIAN LLOYD AzCONA \\ University of Kansas
}

This study aims to contribute to a critical diagnosis of Hurricane Katrina's impact on two communities in the New Orleans area: the Lower Ninth Ward and St. Bernard through a systematic inquiry into the built environment and social inequality. A socio-historical investigation of the Port of New Orleans and its major $20^{\text {th }}$-century infrastructure projects, two ship canals called the Industrial Canal and Mississippi River-Gulf Outlet which transformed the built environment of the Lower Ninth Ward and St. Bernard, is presented. The historical analysis focuses on the political power and ideological discourses of the growth coalition that ruled the port through a nonelected board known as the Dock Board. The author argues that business elites affiliated with the board remade the built environment in their own interest without consideration of the local communities. The implications of this history for a critical understanding of Hurricane Katrina are explored.

\section{Introduction}

On August 29, 2005, Hurricane Katrina moved ashore onto the Gulf Coast. The damage inflicted by the storm cost over 1,000 lives, completely destroyed over 350,000 homes and displaced between 700,000 and 1.2 million people (Gabe et. al. 2005). While the impact stretched across 88 counties, two parishes (the term for county in Louisiana) suffered a disproportionate share of the devastation: Orleans, which is coterminous with the city of New 
Orleans, and St. Bernard, its southeastern neighbor. In New Orleans, 378,206 people out of the 487,779 total population experienced severe flooding; 64,955 of 65,153 residents in St. Bernard experienced severe flooding (Gabe et. al. 2005: 8). In total, 62.5\% of the storm's most affected population resided in these two parishes. Ten months after the storm, at the time of this writing, Orleans and St. Bernard continue their struggle to rebuild their communities.

The immediate reaction of social commentators to Katrina in the popular media posed the question: "How can this happen in America?" Official and unofficial inquiries began to explore this issue. The Army Corps of Engineers first proposed that the storm's power overwhelmed the flood protection system, but an investigation orchestrated by the American Association of Engineers repudiated that argument (Brown 2005; Grunwald 2005). The storm surge from the Gulf of Mexico did not exceed design capacity; to the contrary, the levees failed. ${ }^{1}$ Additionally, the severity of flooding varied across different neighborhoods within the city. A veteran writer for the New Orleans Times Picayune noted how the inundated areas of the city had, in most cases, been developed after 1870 (Marshall 2006). Two of the hardest hit communities within the New Orleans area, where practically every housing unit was destroyed, included the Lower Ninth Ward and St. Bernard. Scientific investigation by the Louisiana State University Hurricane Center documented the floodwater's source in these devastated communities: A navigation canal called the Mississippi River-Gulf Outlet helped "funnel" Katrina's storm surge so as to overwhelm the levees along this waterway and another called the Industrial Canal (Brown 2005). Regarding the social dimensions of the disaster, major news media, such as Newsweek and Time, raised the specter of race and poverty as another factor in need of attention. The discussion also considered the plight of the Ninth Ward since this community had some of the highest concentrations of African American poverty in the city. This brief review of the post-Katrina discourse highlights the built environment and social inequality as key contributors to the storm's damage. ${ }^{2}$ 
A critical, more comprehensive understanding of the storm must further explore these human contributions to the "natural" disaster. This study aims to contribute to a critical diagnosis of Katrina's impact through a more systematic inquiry into the built environment, social inequality and their inter-relationships. In this effort, I conduct a socio-historical investigation of the Port of New Orleans, two of its $20^{\text {th }}$-century economic development projects (Industrial Canal and Mississippi River-Gulf Outlet) and the communities of the Lower Ninth Ward and St. Bernard - which were transformed by these waterways and subsequently destroyed by Katrina.

This paper contains the following organization. To begin, I offer an overview of the urban studies literature on New Orleans. This review lays out the historical context of the city's rampant poverty and power structure. The existing scholarship consistently references a local "aristocracy" who influenced the city's affairs vis-à-vis the control of non-elected commissions. After this review, I explore the relationship between this class of business elites, who I call the Big Easy Elites, and the built environment of New Orleans. For this purpose, I introduce a conceptual framework that draws on political economy and urban sociology. I conceptualize the built environment as a product of capitalist structural dynamics and the agency of the local growth coalitions, whose ranks include non-elected boards. In any urban setting these coalitions act as architects of public policy and proselytizers of growth ideology in order to reshape the landscape in their own interests. At this point I begin the socio-historical study of the non-elected board that governs the Port of New Orleans: the Board of Commissioners of the Port of New Orleans, locally known as the Dock Board. An analysis of the Board's creation and structure outlines how local business associations established the Dock Board and formed a more powerful growth coalition, which I label the Krewe de Growth. The historical narrative addresses the construction of the two navigation canals it produced, the Industrial Canal and the Mississippi River-Gulf Outlet (MR-GO). These two waterways transformed the built environment of St. Bernard and the New Orleans Lower Ninth Ward to stimulate economic growth. The 
analysis interrogates the Krewe de Growth's ideological discourses, which legitimated these growth projects and enabled their completion. Then, it examines the difficulties encountered by Krewe de Growth in its pursuit of subsequent projects due to citizen opposition. After residents defeated the new projects, they called for officials to address the flood hazards of MR-GO. In response to the mounting protest of local residents, Big Easy Elites deployed the same ideological discourses which they previously exploited to legitimate their power throughout the Dock Board's history. Overall, I argue that the political power and ideological discourses of the non-elected Dock Board permitted Big Easy Elites to remake the built environment of St. Bernard and the Lower Ninth Ward in the interests of the local aristocracy and at the expense of residents. I conclude by revisiting the meaning of Katrina in light of these historical patterns of development.

\section{Social Context of New Orleans}

Any attempt to explain "how Katrina could happen in America" must address the relationship between social inequality and the built environment. Toward these ends, I review a wide range of scholarship that examines the political economy of New Orleans (e.g. Hirsh 1992; Gotham 2005). This literature marks the point of departure to address the dynamics of social inequality in the city.

As much of the scholarship pointed out, New Orleans had a high of rate poverty prior to Katrina. In 2000, 27.9\% of the New Orleans population lived below the poverty line. ${ }^{3}$ This high concentration of poor African Americans clearly exacerbated the flood's impact. Because many impoverished residents lacked access to reliable transportation, tens of thousands remained in harm's way as wealthier residents fled in their cars.

However, the association of New Orleans with African American poverty is something relatively new to the city. For most of its long history, a bustling port promoted economic prosperity. Founded at the beginning of the $18^{\text {th }}$ century, New Orleans stood as the nation's fifth largest city in 1850 and continued to overshadow other southern cities until the middle of the $20^{\text {th }}$ century (Mumphrey and 
Moomau 1984). Its economic decline occurred after WWII. By the 1960s New Orleans become a Southern anomaly as it followed the same course as the "rustbelt" cities of the North, rather than the "sunbelt" South, with its sprawling metropolises like Houston and Dallas (Mumphrey and Moomau 1984). Population decline and racial and economic segregation redefined the social landscape of New Orleans (Lewis 2003). City population dropped $20.8 \%$ in three decades, falling from 627,525 in 1960 to 496,938 in $1990 .{ }^{4}$ The city also shifted from a white majority to a black majority between 1970 and 1980 (Perry and Stoke 1987). In 2000, African Americans represented $67 \%$ of the population. The demographic characteristics of the Lower Ninth Ward and St. Bernard further illustrate the emergent pattern of residential segregation. In 2000, the Lower Ninth Ward had a population of 19,515, which was about $91 \%$ black. St. Bernard, which lies adjacent to the Lower Ninth Ward, had a population of 67,229 that was about $88 \%$ white. In economic terms, St. Bernard - which was by no means affluentalso compared favorably to the city with a lower poverty rate (13.1\%) and higher median income. ${ }^{5}$ So what accounts for the economic downturn of New Orleans over the last half century?

The urban scholarship points to macro social processes including deindustrialization and white flight/suburbanization. In the 1960s, the modest manufacturing sector entered a steady decline (Gotham 2005; Smith and Keller 1984; Whelan et. al. 1994). By 2000, manufacturing accounted for a meager $5 \%$ percent of employment. Some industries moved to surrounding areas like St. Bernard-where manufacturing shipments surpassed New Orleans in value in 1997 , although the parish had less than $14 \%$ of the population of Orleans. ${ }^{6}$ On the waterfront, which played a larger role in the city economy, work became more capital-intensive. New shipping methods (e.g. containerization) reduced the demand for unionized, highwage workers on the docks (Smith and Keller 1984; Young and Whelan 1993). While tourism mushroomed during this period of deindustrialization (with the number of hotel rooms growing over $700 \%$ from 1960 to 2000), service industry jobs offered less opportunity to area residents (see Gotham 2005).

White flight accompanied school desegregation in the 1960s 
when white residents moved to surrounding suburbs (Bankston and Caldron 2002). This demographic shift dramatically affected the Lower Ninth Ward as a large population of working class whites moved east to St. Bernard. ${ }^{7}$ For the working class suburb, white flight engendered a population explosion of $360 \%$ between 1950 and $1970 .{ }^{8}$ But for the city of New Orleans, emigration combined with deindustrialization to reduce the size of the middle class and promote more extreme class polarization. For the city's African American population, poverty and unemployment intensified. In the 1970 s, the city had the highest family poverty rate in the country (Glassman 1978). In 1990, over half of the black children in the city lived below the poverty line (Bankston and Caldron 2002). With a declining tax base and antiquated tax code, fiscal troubles handicapped the ability of city government to address the growing challenge of poverty (Smith and Keller, 1984; Whelan et. al. 1994).

Aside from deindustrialization and suburbanization, a number of studies consider the effects of the city's power structure on its economic hardships. Numerous researchers agree that an "established social aristocracy" enjoyed a position of unrivaled privilege in New Orleans (Whelan et. al. 1994: 10). The power of this class crystallized in the final decades of the $19^{\text {th }}$ century (Hirsh 1992; see also Teaford 1984). In response to the rising political influence of ethnic immigrant communities, these Big Easy Elites established a number of non-elected ("depoliticized") boards to govern the city budget, drainage and parks in addition to its port (Hirsh 1992). This maneuver assured that "members of the oligarchy" retained substantive control of city governance (Whelan et. al. 1992: 6). Urban historian Arnold Hirsh offers a cogent assessment of this government restructuring: "Protected from the vagaries of electoral politics, these boards constituted an insular, unelected governing oligarchy drawn from a narrow social and business elite well cognizant of its own interest" (1992: 469). An investigation of the interrelations between social inequality and the built environment must scrutinize this "rigid social structure dominated by a small number of wealthy white families who have been in the city for generations" (Perry and Stokes 1987: 226). ${ }^{9}$ These non-elected boards controlled by elites made the major land use decisions and de- 
signed the city's infrastructure before deindustrialization and suburbanization altered the social landscape.

How does this literature inform a critical examination of Katrina? First, it uncovers the urban processes that gave rise to the social landscape, including the city's high concentration of poor African Americans. In a sense, many better-off residents evacuated over the last forty years, and the abandoned city struggled to remake itself in a postindustrial economy. However, the relationship between social inequality and the (flood-prone) built environment is complex: race and poverty cannot explain the origins of the city's infrastructure examined in this study. The two communities considered here, the Lower Ninth Ward and St. Bernard, differed regarding socio-economic variables prior to the storm; but, as the two most decimated areas in the New Orleans area following Katrina, they shared a common fate with respect to flooding. Their common outcome stems from their shared infrastructure - that is, the navigation canals dug before the city's economic downturn that redrew the social landscape. Therefore, a critical diagnosis of the recent flood must explore dimensions of inequality in addition to race and poverty. It should investigate the "social aristocracy" who wielded the power to create the hazardous built environment through its control of non-elected boards. But first I consult political economy and urban sociology to further conceptualize the relationship between business elites and the production of urban space.

\section{Conceptual Framework}

Urban social theory and sociology provide tools to uncover the social processes through which business elites fashion the built environment in their own interest. But even elites do not act under conditions of their own choosing. Critical urban theorists reveal how the structural dynamics of capital accumulation affect urban phenomena (Harvey 1981, 1996; Lefebvre 1981, 1991; for a overview and sympathetic critique, see Gottdiener 1985). ${ }^{10}$ According to David Harvey, capitalism molds the built environment "in its own image", that is, into a form "appropriate to the purpose of production and reproduction" of a class society-where the 
majority work for the benefit of the few (1981: 265). Since capitalist production must continuously grow, pressure builds for more intensive land uses (Smith 1990). The social inequities endemic to capitalist social structure foster social instability (i.e., "crisis tendencies"), which appears in the built environment (Feagin 1988; Gottinedener 1985; Harvey 1981, 1996). For example, capitalist competition, class struggle and economic cycles redirect investment flows across different cities (e.g., from the "Rustbelt" to the "Sunbelt") and within different areas of a city (e.g., from core to suburb).

Individual capitalists transform the built environment according to their needs with direct private investment or through the mediation of the state (Harvey 1981). The state assures that adequate infrastructure exists for capitalist production; the overriding goal of this public investment is to facilitate capital accumulation by private individuals (Harvey 1981; O'Connor 1971). ${ }^{11}$ Critical urban sociologists document the disproportionate influence of business elites on public policy and observe the unevenly distributed costs and benefits of public investment (Domhoff 1998; Feagin 1998; Gotham 2000; Logan and Molotch 1987). This area of research enriches the structural analysis of capitalism by incorporating the "particular actors whose concrete actions actually shape urban development at the everyday level" (Feagin 1988: 23). Business elites influence public investment by organizing into growth coalitions: alliances of interlocking private and public actors who act in concert to promote urban development (Logan and Molotch 1987).

One powerful instrument utilized by elite growth coalitions to manage the public sector is the non-elected board or commission (Judd and Swanstrom 1994). ${ }^{12}$ The historical work of Teaford chronicles how social elites across the country, who were involved with the local Chambers of Commerce, Boards of Trade or civic organizations, lobbied state legislatures and drafted legislation to establish these "autonomous plutocratic commissions" over the last three decades of the $19^{\text {th }}$ century (1984: 75). Insulated from democratic oversight, "these independent commissions often became bastions of the city's elite...perched proudly at the top of the urban 
social ladder" $(68,76)$. The intimate relationship between public and private sector that continues to this day frequently excludes average citizens from meaningful participation in the decision-making process that shapes the built environment (Squires 1989).

To maintain their privileged position in directing the allocation of public resources, business elites deploy a variety of ideological discourses. As Gregory Squires explains, the "power of private capitals has been advanced by several myths pertaining to the role of the public and private actors" (1989: 4-5). Urban scholars use the term privatism to encompass the cultural presuppositions that sanctify the market and private sphere while deriding the unsavory "politics" of the public realm (Barnekov et. al. 1993; Levine 1989; Warner 1968). This ideology protects business from meaningful public oversight. It also validates anti-democratic institutions, such as non-elected boards, that privilege elite interests by subordinating public authority to economic criteria (e.g., efficiency) and heroicizing the "character" of business leaders (Judd and Swanstrom 1994). The ideology of growth legitimates the state subsidization of private capital accumulation, or "economic development", above other social goals (Smith and Judd 1981). In the public sphere, growth coalitions frame the individual pursuit of wealth as a socially benevolent endeavor that fosters general community progress - e.g., expansion of the tax base or job creation (Logan and Molotch 1987). These ideological representations obscure the uneven distribution of the growth benefits and hide its social costs. As Smith and Judd state, pro-growth policies "often directly transfer resources from middle income and working people to the "haves" on little more than blind faith that growth is in the public interest" (1981: 191). I view privatism and growth discourses as complementary ideologies advanced by growth coalitions. When effective, both discourses mediate the material transformation of the built environment by manufacturing a social consensus for new development.

Returning to the case of New Orleans, these concepts help map the social processes that formed its hazardous built environment and set the stage for Katrina. At the structural level, interport competition, new shipping technologies and cycles of world 
trade are a few of the capitalist dynamics that shaped the production of urban space. At the level of local practice, Big Easy Elites used private business associations and the non-elected Dock Board as a growth coalition. Through this Krewe de Growth they managed public policy to construct infrastructure projects in the Ninth Ward and St. Bernard. The ideology of privatism excused the social inequality inherent in this arrangement. The ideology of growth justified the public subsidization of private accumulation. Two distinct discourses appeared in the formation of its pro-growth policies: a discourse of modernization and the discourse of entrepreneurial structuralism. The former asserted the need to subjugate the urban landscape, especially the Mississippi River, to serve commerce. The latter argued that competitive pressures and economic imperatives dictated what changes were in order. I will now move to the historical portion of this paper beginning with the origin and structure of the non-elected board that governed the port, shaped the landscape of the Lower Ninth Ward and St. Bernard, and changed the lives of their residents.

\section{Creation of the Dock Board}

From the time of the city's founding, the port dominated the New Orleans economy, more so than any other major port city in the country (Lewis 2003). All business was historically linked to the port in some way (Schill 1974), and these businesses consistently composed one of Louisiana's most powerful economic interest (Stiegman 1971). ${ }^{13}$ The environmental historian Ari Kelman chronicles their power to determine the city's built environment. He documents how commercial elites "remade their urban riparian ecosystem ...to make the unpredictable predictable in the service of capitalist development" over the course of three centuries (2003: 14-15). A history of New Orleans' built environment starts with the port and the formation of the Dock Board at the end of the $19^{\text {th }}$ century.

The people who own or work for port businesses organized into various groups. Labor unions attained a strong presence on the docks by the turn of $20^{\text {th }}$ century, representing both white and black work- 
ers (Rosenburg 1988). Likewise, owners formed trade and business associations, such as the New Orleans Board of Trade, the New Orleans Steamship Association, and the Chamber of Commerce to the New Orleans Area. The Big Easy Elites, who controlled these associations, had direct financial incentives to intensify land use along the waterfront and encourage economic activity on city waterways. Collectively these private associations constitute a growth coalition (Logan and Moltch 1987). While all Big Easy Elites did not have a direct stake in the port, their notoriously tight-knit community - which affiliated in exclusive social clubs and Mardi Gras "krewes" and lived together in the Uptown area (Chai 1979) suggests a cohesive class with a unified interest (Domhoff 1998).

Near the end of the $19^{\text {th }}$ century, chaotic conditions plagued the waterfront (Kelman 2003; Martinez 1954). Competition between port entrepreneurs led to overproduction of wharves, berths and other facilities. The glut of capital hampered profits and, thus, discouraged basic maintenance of the built environment. The dilapidated working conditions stimulated more intense labor conflicts culminating in a number of strikes - where longshoremen even united across racial lines to the horror of the all white Big Easy Elites (Rosenburg 1988). Therefore, unregulated socio-spatial conditions posed a threat not only to the business order, but the larger social system of power relations.

In 1895, the New Orleans Board of Trade, considered the most powerful business association in the city from 1879 to 1928 , organized a conference to "investigate" the conditions of the port (Martinez 1955; Schill 1974). The growth coalition inquiry drew up a text that became state law the following year. Louisiana Act No. 70 of 1896 created a new institution, a port authority, officially named the Board of Commissioners for the Port of New Orleans, which came to be known as the Dock Board. The speedy adoption by the Louisiana Legislature indicates the political favor enjoyed by the port growth coalition. The Louisiana government did not hesitate to hand state powers to Big Easy Elites.

The formation of the Dock Board consolidated the interest of the port growth coalition in a non-elected board. By law, this public authority functioned to reproduce the conditions of capital accu- 
mulation in a jurisdiction sprawled across the three parishes of Orleans, Jefferson, and St. Bernard. Act No. 70 mandated its central purpose to intensify land use: to "improve the wharves and other facilities of the Port and greatly develop and expand commerce by removing many of the obstacles now placed in the way of advancement." This developmental function became an instrument to channel public funds into capital improvement projects, socializing the cost of production while privatizing the benefits (see O'Connor 1971). In Act No. 70 the State Legislature also handed the Dock Board powers that included "all things necessary or proper for the government, regulation, development and control of the business of such ports." This regulatory function attenuated the profit-eating contradiction of capitalist competition on the waterfront, allowing for the centralized planning of the port's built environment. Thus, the formation of the Dock Board represents an initiative by elites to remedy the contradictory nature of capitalist production and circulation by harnessing pubic power and resources.

Through direct control, the port growth coalition and the New Orleans social aristocracy wielded the power of the Port Authority. The administrative structure and the appointment process of the Dock Board guaranteed the hegemony of Big Easy Elites. Act 70 specified that all commissioners must be "predominantly identified with the commerce or business interest of the Port of New Orleans." Later in 1940, a Louisiana constitutional amendment revised the appointment process to free it from "politics" and formally tie the growth coalition to its administration. Five business and trade associations were selected to be nominating organizations. These included the New Orleans Association of Commerce, the New Orleans Trade Association, the New Orleans Clearing House, the New Orleans Cotton Exchange, and the New Orleans Steamship Association. ${ }^{14}$ The original and subsequent legislation established a Board structure which guaranteed the direct control by Big Easy Elites vis-à-vis the nominating organizations. ${ }^{15}$ The Port growth coalition provided both the "selecting apparatus and the single largest group of potential appointees" (Schill 1976: 116). Together, the Dock Board and private associations comprised the Port Krewe de Growth. 
The justification for this plutocratic arrangement evoked the ideology of privatism. Richard B. Montgomery, Jr., the lawyer who drafted the legislation, explained its logic:

We felt that the Dock Board could only get back into proper operation by ... having a Board completely out of polities run by businessmen, steamship men, bankers, and people like that. (quoted in Schill, 1074: 15).

Louisiana Governor Jones justified the amendment by claiming it ennobled "men of character, men of irreproachable reputation, men of vision" to "unselfishly strive to build our port of New Orleans to its rightful place among the great ports of the world" (quoted in Brenton 1953: 24). Montgomery and Jones imply that the business of government is business, which should be handled by businessmen. Therefore, port affairs needed to be freed from the "politics" of the city council and other democratically accountable institutions.

In this growth coalition, the lines between public and private frequently blurred, but the distribution of cost and benefits crystallized. The early history of the Board illustrates the cozy relationship between the private and public sector, and reveals an elite community very interested in the viability of this institution. In the years following its creation, a dearth of public funding threatened the Dock Board's survival. To keep it afloat, local banks (e.g., Hibernia National Bank) issued emergency loans backed by mere personal guarantees from the commissioners (Martinez 1955). Other companies, such as Leyland Steamship, Harrison Steamship, United Fruit and Southern Pacific, financed the construction of new facilities on behalf of the Port by floating interest-free loans in exchange for "first call on berth privilege" (Martinez 1955; Rosenburg 1988; Stiegman 1971). Port commissioners later credited these initiatives from the business community for the Dock Board's survival. These informal arrangements evidence a social consensus within the social aristocracy regarding the management of the city's largest economic engine. They also suggest who likely benefited from its management.

The Port Authority enjoyed fiscal powers, regulatory powers, and developmental authority to create a built environment friendly 
to commerce. Administrative control of public waterfront property and facilities made this institution the premier property manager of the port. Its dependence on rents and land values wedded the financial health of the public authority to the growth of river commerce and the exchange value of its property. And like any other entrepreneur - and, at times, with the state power of eminent domain - the Dock Board enjoyed the legal right to accumulate more property if "necessary or proper for the government, regulation, development and control of the business" (Louisiana Legislature Act No. 70 1896). In addition, state subsidization of the Dock Board through taxes and bonds provided public resources for capital improvements to increase the value of its property. Through its political power and access to public resources, the Dock Board could redesign the socio-spatial conditions of the city on a far grander scale than individual businessmen. Nonetheless, these larger projects could still serve the interests of these business elites - and without risking their personal fortunes.

\section{Producing the Built Environment Part I: The Industrial Canal}

The first major project arranged by the Port Krewe de Growth was the Inner Harbor Navigation Canal, known as the Industrial Canal, which was completed in 1921. Without assistance from the federal government, the Dock Board coordinated the production of a $5 \frac{1}{2}$ mile long, 30 foot-deep channel. The canal is located downriver from the French Quarter; it runs north from the Mississippi to Lake Pontchartrain, cutting through the New Orleans Ninth Ward. The radical alteration to the built environment, as well as what used to be swamplands, promised "unlimited industrial development" (Board of Commissioners 1926: 31). With this project the Krewe de Growth aimed to acquire new waterfront property in order to draw more cargo and attract new industry.

An emergent discourse of Port modernization packaged the growth ambitions of the Big Easy Elites. The modernization discourse rebuked the New Orleanian "mystic reverence" for the Mighty Mississippi and the complicit satisfaction for its "natural 
advantages" (Bolding 1969). The words of a Louisiana governor reflected this disenchantment with the extant environment: "while there are these great natural outlets, commerce seeks the channel of least resistance... and if New Orleans wishes to enjoy its great advantages, man must come to its assistance" (quoted in Kelman 2003: 148). Traditional meanings of the river withered with the demiurge of an instrumental rationality that promised a new avenue to economic growth. In material terms, modernization translated into more space for industrial development and a rationalized nature not possible on the riverfront. Specifically, proponents argued that locks would allow Lake Pontchartrain to set the canal's water level, rather than the unruly and fluctuating Mississippi. More control offered a better environment for industries like ship building. The waterway's local name denotes this industrial ambition and indicates how the resulting landscape objectified this discourse of modernization.

The magnitude of this socio-ecological reworking necessitated the concentrated economic and political power offered by the maturing Krewe de Growth. With the support of the trade associations, the Dock Board raised the capital, obtained right-of-ways, coordinated the labor, and solicited technocratic expertise from the world-renowned engineer responsible for another major waterway: the Panama Canal. Local geographer, Richard Campanella summarizes the scale of this socio-ecological re-engineering: "With labor gangs, mechanized excavators, pile drivers, dredges, dynamite, and other implements, the largest construction project in New Orleans history was rapidly redefining the geography of the Crescent City" (1998: 74). The waterlogged soils of the swamps between the lake and the city challenged work crews; existing infrastructure, including railroads and the sewer system, compelled the reorganization of the built environment. It was no small accomplishment by the Krewe de Growth.

In addition to producing an optimal landscape for business, the Industrial Canal restructured social relations. First, new property relations with respect to the land along the canal gave the Dock Board more management authority than it held with the riverfront. The Board was able to liberalize its leasing policy and offer gener- 
ous long-term leases for up to 99 years (Martinez 1955). ${ }^{16}$ Consequently, the Industrial canal did not just lubricate commerce by subduing nature's unpredictability and making room for new industry; it bolstered the power of the business class by extending its control of the new public resource. The augmented status of business elites also appeared in the modernization discourse after the projects completion. A privatist theme celebrated the creative ingenuity of the entrepreneurial spirit to improve an "outmoded" Mississippi River. The words of one business commentator illustrate this point:

[The] people of New Orleans have begun to realize that the natural advantages alone are not enough, but must be supplemented by thought and enterprise ... Natural advantages plus intelligent human enterprise will for all time safeguard New Orleans' larger interests." (New Orleans Official Daily Court Record, September 9 1943)

When Big Easy Elites touted this accomplishment, they affirmed their privileged position to equate their own interest with "New Orleans larger interest."

While the Industrial Canal was certainly good for the Big Easy Elites, for citizens residing in its proximity it brought disturbances long before Katrina. In the Ninth Ward, the Dock Board displaced a number of local residents, and bisected the community. The new waterway erected a physical boundary, introduced new hazards, and isolated a portion of the Ninth Ward and St. Bernard Parish from the rest of the city. Symbolic boundaries accommodated the material form of the new landscape as the fragmented neighborhood became known as the "Lower Ninth Ward."

\section{Producing the Built Environment Part II: The MR-GO}

The Mississippi River-Gulf Outlet (MR-GO) is a "tidewater" channel that connects the Industrial Canal to the Gulf of Mexico. This 76 mile canal extends from the Lower Ninth Ward, passes through eastern New Orleans, traverses the marshes of St. Ber- 
nard Parish and cuts 40 miles off the trip from the Inner Harbor to the Gulf than the alternative path of the meandering Mississippi. Opened in 1963, this project was formally completed in 1967 . With an original width of 500 feet and a depth of 36 feet, the MR-GO was large enough to accommodate most ocean-going vessels in its early days of operation. ${ }^{17}$

The idea to build a "better river" connecting the Port to the Gulf dates back to the early $19^{\text {th }}$ century. Proposals for a direct route occurred as early as 1826 when the Louisiana Legislature introduced a resolution for the "Tidewater Channel" (Times Picayune 1957 December 11: 1). But early initiatives never gained traction until the opening of the Industrial Canal — which provided "a starting point of a long-discussed short-cut tidewater level channel to the sea" (Times Picayune 1963, September 9). For example, one business elite with the Association of Commerce brought both the ideal and real canals together: "completion of the Inner Harbor and Industrial Canal now make possible the dredging of a ship channel of 40 or 45 feet depth direct to the gulf" (New Orleans States Item 1923 November 20:15). However, this initial optimism for the channel waned with the onset of the Great Depression. The earnest mobilization of a growth coalition in support of the "tidewater channel" began in 1943 (Bolding 1969). Completion of the MR-GO required three conditions: 1) favorable economic circumstances, 2) an active and powerful growth coalition, and 3 ) the crystallization of a new growth ideology. I explore these overlapping contributions which made possible the production of the infrastructure that later channeled the storm surge of Hurricane Katrina.

\section{Wartime Shipping Bonanza}

The port prospered during WWII. From 1937 to 1947, New Orleans experienced $41 \%$ growth in foreign trade (Board of Commissioners 1947 April). While the entire nation witnessed a new prosperity, Big Easy Elites especially thrived as they courted higher volumes of traffic than competing ports. Fortune Magazine attributed this success to the ability of "boosters" and the "city's top 
citizens" to cultivate a "good sales-engineering job." These placeentrepreneurs marketed "every conceivable service from free secretarial assistance to oysters Rockefeller at Antoine's" (1948: 102). In addition to its "overpowering display of charm", the growth coalition erected new office space and port facilities to encourage growth, which included the International Trade House, the PanAmerican Building, and the nation's second Free Trade Zone. A new seaway complemented a "pattern" or "blueprint" to sustain the "shipping bonanza" after the war (102).

Ports live and die by the ability to attract more cargo (Weigend 1958). After the war, labor conflict, industrial innovations, and competitive pressures threatened the security of Port profits and growth. The precariousness of their success stimulated the anxiety of Big Easy Elites. The Dock Board explained their insecurity through the rhetoric of the privatist ideology:

Port Development is a cold-fact business ... No simple panacea or formula ... is going to overcome the constant and intense competition between the many gateways and between the many forms of transportation serving them. (Board of Commissioners 1940: 10)

Intensified inter-port competition challenged the status of New Orleans as the nation's second largest port when federally financed infrastructure improvements on the Great Lakes and the Texas coast enlarged the ports of Chicago and Houston (Kenyan 1973; Juhn 1967). Additionally, unions were active on the docks (Army Corps of Engineers and and United States Maritime Commission 1947). To the business community, frequent strikes and labor gains, such as the forty hour work week, challenged elite authority and limited the cargo capacity of river facilities (Board of Commissioners 1947). Furthermore, new productive forces in shipping (i.e. larger vessels) reduced the berthing capacity of the city's wharves. Unruly workers, larger ships, and bigger competitors threatened the postwar bonanza, leading Big Easy Elites to question the adequacy of waterfront facilities. In this context an ad hoc coalition emerged in order to sustain the city's economic virility with a "seaway" extension from the port to the Gulf. ${ }^{18}$ 
The Rising Tide of a Growth Coalition

Big Easy Elites formed an organization called the Tidewater Development Association (TDA) to promote the seaway. This ad hoc growth coalition worked closely with the Dock Board to convince the Army Corps of Engineers to embrace the project. The TDA leadership reflected the elite hegemony in the historic event that transformed social and ecological landscapes of the Ninth Ward and St. Bernard. Its two most influential members were Col. Lester F. Alexander and A.B. Freeman, both of whom chaired the growth coalition. Before founding the association, Col. Alexander served as a commissioner for the Dock Board. He had previously worked as an engineer for the Corps on the lower Mississippi River. After his tenure with the federal government, Col. Alexander started his own contracting firm and a shipbuilding company on the Industrial Canal (Board of Commissioners 1950 February: 16, Juhn 1967). His role demonstrates not only the institutional linkage between the private sector, the Port of New Orleans, and the federal government; his investment on the Industrial Canal gave Alexander a direct financial interest in a project that would increase the value of his property. A.B. Freeman represented the highest echelons of the New Orleans social aristocracy. As a mark of his prestige, Alfred Bird Freeman appeared in Who's Who in America. He worked as a Coca-Cola executive and founded Wesson Oil. He also served as a port commissioner, held membership in the most exclusive social club in the city (Boston Club), and served on the Tulane Board of Trustees (Board of Commissioners 1948 January: 11). The TDA proved an enormously important addition to the Krewe de Growth.

In the summer of 1943, a pair of events kicked off the campaign for the Tidewater Channel. At the behest of Alexander, local civic groups sponsored a public spectacle entitled "Greater Port Day" in order to celebrate the port's accomplishments and promote the seaway (New Orleans Item 1943 July, 27). Shortly thereafter, the TDA arranged a public meeting at the Roosevelt Hotel located in downtown New Orleans. A general from the Army Corps of Engineers coordinated the meeting, and the attendance of over 
500 businessmen impressed the Army. Over 50 briefs were submitted to the Corps in support of a channel from the Industrial Canal to the Gulf of Mexico, which included formal endorsements from the Dock Board, its nominating organizations, and labor unions (Board of Commissioners 1943 August).

However, a local coalition from the West Bank of the River stepped forward to jockey with the Dock Board and TDA for the favor of the Army Corps. A contingent of Jefferson Parish politicians and business interests, calling themselves the Mississippi River Valley Seaway Canal Association, sponsored an alternative site from the West Bank. Competition between plans for an "eastbank seaway" and "westbank seaway" ensued for five years (Times Picayune 1963, September 30: 1). But the Krewe de Growth expended superior resources to build consensus for the Industrial Canal site. The Dock Board and TDA financed a series of "investigations" by engineering firms and a former Army colonel. The resulting reports supported their position: the Industrial Canal offered the only practical place for port expansion, and the Army Corps of Engineers agreed (ACE 1951). ${ }^{19}$ The Corps also noted the legal authority of the Board of Commissioners to oversee the well-being of port affairs, and complimented the Dock Board's earlier achievements (e.g. the Industrial Canal). Therefore, following the second public meeting in New Orleans in March 1947, the district engineer endorsed the "eastbank seaway" (Times Picayune 1963 September 30: 1). Thus, in the early years of the campaign, the Krewe De Growth won the site competition based on its privileged legal authority and its superior ideological resources. After this victory, the Dock Board and TDA took the case to Washington.

Following district approval, the canal plan trickled through the Army Corps of Engineer's bureaucracy (ACE 1951; for outline of the decision-making process during this period, see Eckstein 1961: 2-8). After renaming the Tidewater Channel the Mississippi RiverGulf Outlet, the Corps sent the plan to Congress. In the halls and backrooms of the U.S. Government, MR-GO proponents competed for authorization with the profoundly more costly St. Lawrence Seaway Project from the Great Lakes, which had the backing of 
key Midwestern business allies and, consequently, more support from Congress. At this point, the onset of the Korean War inspired President Eisenhower to suspend all new ACE projects (Eckstein 1961).

Against these unfavorable circumstances, the Krewe de Growth sustained its drive. TDA members testified before Congressional hearings on behalf of the channel. After becoming president of the association in 1954, A.B. Freeman instigated the courtship rituals noted in Fortune Magazine to woo the Midwestern businesses and congressional representatives. In 1955, a series of "inspection tours" aboard a Dock Board yacht and some fine dining at Antoine's helped "spotlight the truth of the project," as Senator Al Gore Sr. put it (Times Picayune, 1955 December 7: 3). Big Easy methods of authenticating truth in the finest restaurants of the French Quarter helped secure the pledge of Congress. Authorization arrived in the 1956 River and Harbors Act.

\section{Tidewater Ideology}

The power of the Krewe de Growth was manifested in its ability to organize and control the discursive practices dealing with the canal, and its ability to symbolically construct an "absolutely essential" built environment for both the city and nation. Through public meetings, private meetings, inter-organizational correspondences, reports, presentations, governmental investigations, legislation, dinner parties and boat rides, a coherent pro-growth discourse developed in support of the Mississippi River-Gulf Outlet. In all the talk and text around the Tidewater Channel, two themes appear central to the materialization of the project. First, the growth discourse defined port economic development as an absolute social necessity for both the national economy and national security. Second, the growth discourse produced a symbolic landscape that promised material aplenty. This ideological production proved essential in obtaining the government seal of legitimacy: "economic feasibility."

In what I call the discourse of entrepreneurial structuralism, economic elites consistently reiterated a rhetoric of need that 
declared the MR-GO "absolutely essential" to the welfare of the port, city, state, and nation. ${ }^{20}$ This discursive construction of necessity employed a redundant vocabulary of obligation, highlighting the military and commercial value of the tidewater "emergency outlet" to "national defense and general commerce" (Times Picayune 1943 August 6: 1; Louisiana Legislature Concurrent Resolution 18; ACE 1951). Military and economic demands supposedly made the seaway an "urgently needed and extremely important artery to the sea" (Times Picayune 1957 December 11: 3).

The discourse of entrepreneurial structuralism represented the Mississippi River and its surrounding built environment as unable to sustain urgently needed growth. In an editorial, the Times Picayune situated the project in the historical moment: "The United States must trade over the world in a big way or its industrial machine will stagnate," and to increase trade, "the country needs ports of a large capacity" (Times Picayune 1957, December 10: 15). Advocates asserted that the seaway would not only meet the demands of a more competitive "new economic world" (Board of Commissioners 1943: 8) but would "bring about economies that will stimulate world trade" (Times Picayune 1943, August 5: 1-2). By doing so, the port boosters claimed that no "project... would contribute more to hemispheric solidarity" (Board of Commissioners 1943: 8). The emphasis on trade at the national level helped construe New Orleans' economic development as a national concern. The rhetoric of need equates the well-being of a larger public with local capital accumulation. As Louisiana Legislature concluded: "prosperity for the citizens of New Orleans and the State of Louisiana" rested upon "the growth and expansion of the Port's business" (Louisiana Legislature 1944).

In the discourse of entrepreneurial structuralism, the built environment itself demanded new infrastructure. Tidewater proponents declared existing infrastructure to be unacceptable due to the changing nature of shipping. Larger vessels accentuated the "definite need for a deep, safe, and dependable access channel to the sea" (Louisiana Legislature 1944). Specifically, the Industrial Canal lock was represented as a "bottleneck" or "immovable body" impeding the "irresistible force of growing volumes of commerce" 
(Times Picayune 1963, September 29: 1). The structuralist language of the Krewe de Growth universalizes the interest of Big Easy Elites by masking the benefits to local businessmen as those of the state and nation.

The discourse also conjoins the interest of the growth coalition with "national defense." Tidewater boosters sold the new channel as a vital investment in national security (ACE 1951). Promoters drew attention to ostensible strategic benefits of a second outlet to the sea. The words of the Army Secretary demonstrate the military logic:

The recent war demonstrated that harbor facilities, if dispersed and provided unrestricted access to the sea, are rendered inoperative by air or sea action with great difficulty... Hence wide dispersion of harbor facilities should be provided for in any plan for comprehensive port development. New Orleans riverside wharves, of timber construction on long wood piles, cannot be expected to resist destruction by bombing as practiced in the recent war, and attack by atom bomb now possible . . ., so preferably additional installations in the interest of national defense should be located off the river with an unrestricted outlet to the sea and access to the river through locks which from a security standpoint, can be considered as alternative entrances. (ACE 1951:42)

The proposed canal purportedly secured the nation from nuclear holocaust. Discursively, the MR-GO became a pro-growth project that could both promote profit and save lives.

The Krewe de Growth also continued to use of the discourse of modernization. In the construction of the symbolic landscape, Big Easy Elites distinguished civilized nature from the "inadequacy" and "hostility" of its barbarian ancestor, who opposed commerce and progress. Col. Alexander demonstrates this representational strategy:

The Port's life-line should not depend entirely upon a crooked, fog-covered, silt-bearing, temperamental river channel-a sure, safe and dependable 40-foot tidewater channel from New Orleans to the sea should be provided... New Orleans' port growth 
should not be restrained or restricted like a Chinese girl's foot. (New Orleans Item 1943 July 27: 21).

This discourse of port modernization promised a safer, shorter and more economical route to the sea-that is, a human-engineered waterway freed from the river's natural obstacles to commerce: fogs, sharp turns, shoaling and strong currents. As with the Industrial Canal, human intervention intended to rationalize and administer nature "to create the most favorable environment for enterprise" (Official Daily Court Record 1943, September 9).

For the local communities, MR-GO supporters made fantastic promises of an "industrial revolution" and "new vistas" along the canal (Times Picayune 1957 December 11: 3). The forecast of new growth assured the Army Corps of Engineers, which certified the symbolic channel as a "feasible project" (1951). ${ }^{21}$ The Congress defines feasibility to mean that "the benefits, to whomsoever they may accrue, are in excess of the estimate cost" (quoted in Eckstein 1961: 2). But these promises never materialized in St. Bernard and the Lower Ninth Ward. And as with the Industrial Canal, immediate social costs arrived long before Katrina. In the competitive quest for profit, the Krewe de Growth once again displaced residents and restructured the patterns of daily life. Ideological discourses of the growth coalition not only downplayed their own interests; they also hid the social costs by abstracting the local residents from the landscape. Repeated references to the "marshlands" or "lowlands" obscured the social life (e.g. fishing, hunting, residence, work and play) embedded within the land. Any acknowledgement of residents was conspicuously absent until construction began (Times Picayune 1957, December 11). One paper described the area east of the Industrial Canal as "some 34,000 acres of unused low lands" (Official Daily Court Record 1945, March 20). The Louisiana Legislature declared this landscape to be "practically valueless" (Louisiana Legislature 1944). However, people did live and work in the area, and some were directly displaced at Shell Beach, the trapper community in St. Bernard. But people-less lands are more easily commodified, quantified, and expropriated (Cronon 1983; Willhems Braun 1998). 


\section{The Built Environment and Citizen Outrage}

Following the construction of the MR-GO, the Dock Board pursued two more major projects that would have, once again, remade the built environment in the Lower Ninth Ward and St. Bernard. The first was the Lock Replacement Project. This project aimed to construct a new lock linking the Mississippi River and the Industrial Canal in order to allow larger ships to enter the inner harbor. The Rivers and Harbors Act of 1956 already authorized the new lock when deemed "economically justifiable" (Luria and Soll 1996). The second project of the Dock Board, which was contingent upon a new lock, was called Centroport 2000. Centroport was a plan to completely reorganize the built environment of the port, moving most facilities off the Mississippi to the Industrial Canal and the MR-GO (Bechtel 1970). However, the Dock Board encountered intense citizen resistance against these plans. Local opposition successfully defeated the latter and delayed the former for decades. By the 1990s, the citizen struggle against the Port Krewe de Growth matured into a movement to close the MR-GO.

In a sense, the Dock Board proposals responded to a changing economic climate brought by deindustrialization. Two aspects of this process which affected the port included containerization and the rise of tourism. In shipping, the "container revolution" transformed the movement of cargo (Kenyan 1971). Containers drastically increased the need for fixed capital (e.g. gantry cranes) and land for marshaling yards (Gulf South Research Institute 1968; Kenyon 1970). While containerization magnified world trade, port cities derived few benefits from the revolution of the means of transportation. Its high capital intensity exacerbated inter-port competition, downsized the workforce, and catapulted the shipping industry's demand for public subsidization (Helling and Poister 2000). New Orleans stevedores and shipping interests located on the riverfront were not in a good position to adopt the new technology (Bechtel 1970; GSRI 1968). Limited space and inadequate rail and truck infrastructure along the river convinced the Dock Board that the Industrial Canal and MR-GO offered the best location for container terminals. 
In the post-industrial economy of New Orleans, tourism arose as a leading sector. Tourism promoters began challenging the privileged status of the Dock Board and its monopoly over riverfront property. With the help of elected politicians, business elites new to the city - and therefore not of the old social aristocracy - funneled public investment into tourism developments, such as the Louisiana Superdome; and, major hotel corporations followed their lead by erecting high-rises outside the French Quarter (Smith and Keller 1984: 134-137). The surge of public and corporate investment in New Orleans tourism sparked interests in the Dock Board's riverfront property in and near the French Quarter. Plans to convert the riverfront for non-industrial uses appeared in the late 1970s (Young and Whelan 1993). By the mid 1980s competing agendas for riverfront property assumed a more hostile quality. Another growth coalition and non-elected board, the Audubon Commission, successfully pressured the Dock Board to sell more property for tourist development (Young and Whelan 1993). In this context of competing growth coalitions and new methods of cargo handling, the Krewe de Growth initiated its new campaigns (Bechtel 1970).

In their effort to mobilize public support for additional alternations to the St. Bernard and the Lower Ninth Ward built environment, the Big Easy Elites redeployed the discourses of modernization and entrepreneurial structuralism. The Dock Board initiated a public relations campaign to, in the words of its president, "take our story to as many people as possible" and "educate" the general public (Atkinson 1969: 2). President Robert R. Barkerding explained the ideological "story":

Our people - and I mean every man, woman and child in the city - should be more port conscious and arise to the need of educating our present and future citizens to just how much our city's progress is dependent on the greatest possible development of the port's potential. (Atkinson 1969: 1)

Implying that economic growth automatically benefits everyone, the modernization discourse tied the well being of every resident to new development in the port. It also singled out the industrial canal lock as a barrier to "our city's progress." On this theme, co-direc- 
tor of the port and former colonel from the Corps, Col. W. H. Lewis, lambasted the "completely inadequate" lock as a "shipping albatross" (5). The discourse of entrepreneurial structuralism discussed the port in terms of a "prosper or perish" binary. The imperative of containerization was its great concern. But paradoxically, the Dock Board president framed this need in terms of jobs:

[L]et's just say if we don't have these new container terminals in two or three years, then the character of the Port of New Orleans will change. It will become a pushbutton port, dealing in commodities that don't require a lot of people to work. (quoted in Atkinson 1969: 2)

The returning Tidewater Development Association took the lead in disseminating propaganda by mailing brochures to St. Bernard residents, which prophesized 10,000 new jobs with the Centroport (Mazmanian and Nienaber 1979). Considering the capital intensive nature of container terminals, such grand proclamations clearly overstated the benefits of this growth project.

However, Big Easy Elites encountered new obstacles. In the Lower Ninth Ward and St. Bernard, residents challenged the Dock Board. The Dock Board's previous success in socializing the costs and privatizing the benefits fueled local resentment. The first signs of opposition appeared in 1960 at a meeting between the Dock Board and St. Bernard residents. The Dock Board called the meeting to notify residents of the new lock, but intense opposition cut the meeting short. A local lawyer explained the problem:

The Dock Board, as you can remember, some few [years ago] held a hearing as to what they were going to do for the parish on the MR-GO...And what happened? The meeting was quickly discontinued because there was too much opposition for that Gulf channel, and then they came back and threw it down our throats and told us that they had deadlines to meet and if we didn't agree to give them the ground they were going to court to take it away from us - that's what they did - that was what they intend to do here (quoted in Mazmanian and Nienaber 1979: 85) 
Excluding residents from the decision-making process affecting their own built environment created new difficulties for subsequent projects. Indifference by the elites running the non-elected board engendered local antagonism toward its unaccountable power.

Environmental contradictions to economic growth on the local and national level also hindered the realization of the Centroport program. In 1965, an unforeseen event further eroded the credibility of the Krewe de Growth. Betsy, a category 3 hurricane, directly hit New Orleans. Forty years before Katrina, this storm "pushed a wall of water up the Industrial Canal, flooding the Ninth Ward and St. Bernard Parish" (McQuaid and Schleifstien 2002: A7). Despite Dock Board and Corps denials, many residents attributed flooding to the MR-GO (Shallot 2000). At the national level, another problem for the Dock Board came with the passage of the National Environmental Protection Act in 1969. NEPA empowered citizens with some procedural rights which gave residents the means to obstruct growth projects (Logan and Molotch 1987). Litigation provided an invaluable tool for residents to contest the power of the Krewe de Growth.

Encountering these contradictory effects to its previous accomplishments, the Dock Board abandoned the Centroport plan in the 1980s. Nonetheless, Big Easy Elites committed to a lock replacement project that would triple the size of the existing lock in the Ninth Ward. A twenty-five year confrontation between the Krewe de Growth and neighborhood groups ensued (Luria and Soll 1996). The Corps attempted to placate residents through "working groups" and a "mitigation plan" (Luria and Soll 1996). Many community groups, including the Holy Cross Neighborhood Association, the Association of Community Organizations for Reform Now (ACORN) and All Congregations Together, sustained vigilant opposition to the "modernization program" (Warner 2000). A letter to the editor by John Koeferl, president of the Holy Cross Neighborhood Association, expressed their position in historical context:

This neighborhood was here 100 years before the canal. People yet living bear witness that poor families were thrown in the 
street and their houses torn down to make way for this canal... The [new lock] project is on a collision course with this community and threatens its basic values, security and health" (Koeferl 1999: B6).

Nonetheless, Congress appropriated funds in 1998 (George 2003). Then, national groups joined the opposition, including U.S. Public Interest Research Group, Friends of the Earth, and Taxpayers for Commonsense; and lawsuits delayed the half billion dollar project (Times Picayune 2001). Another letter to the editor by Octavia Turner of ACORN articulated resident concerns:

This project is outdated and unnecessary, and it will needlessly disrupt our quality of life for the next 12 years, causing terrible problems with construction noise, damaged houses, business closings, bridge closings, unsafe conditions for school children...(Turner 2000: B4).

Business groups in the port growth coalition defended the lock project with the modernization discourse. A spokesman from American Waterways Operators, a barge and towboat trade association, reiterated the standard argument:

[The lock had] been operating inefficiently because of its age. A new lock changes everything...A reliable, modern lock spurs growth throughout the Gulf South" (quoted in Warner 2000, April 21:A1).

For residents, a wider lock and extended construction period only promised greater marginalization from the rest of the city (Turni 2001). For the Krewe de Growth, a new lock offered an opportunity for more intense development along the Industrial Canal. "The value of that property is going to be much greater," Ron Brison, director of the port, explained (Darce 1999: C1). This feud between local residents and the Krewe de Growth continued until the eve of Katrina (Schleifstien 2005).

After residents managed to fend off the Centroport, an organized initiative to close the MR-GO slowly crystallized in St. Bernard Parish. In the late 1980s, local groups, such as the St. Bernard 
Sportsmen League, allied with state environmental organizations (Ledoux 1993). At the state level, a broad environmental movement to restore Louisiana coastal wetlands garnered wide support for coastal protection and restoration. This grassroots initiative drew attention to the environmental cost of the MR-GO. Some attributed over 40,000 acres of wetland loss to this "marsh-eating monster," and noted how the canal itself swelled from an original width of 500 feet to 2,500 feet in some places (Caffey and Leblanc 2002). As the broader restoration movement gained steam, it morphed into a state and federal campaign to acquire $\$ 14$ billion in federal funds to "save the coast" (see Coast 2050 www.lacaost.gov/). Ironically, the Army Corps of Engineers became a leading cheerleader for restoration and the mega-projects it would entail. The role of the "new Corps" as environmental advocate left it vulnerable to obvious charges of hypocrisy for its commitment to the MR-GO. Public meetings designed to drum up support for restoration turned into forums where residents contested the canal, crying that "the MR-GO has to Go!" (Boyd 2004). Aside from the environmental costs, the economic rationale for the canal floundered when ship traffic dwindled to a trickle (Multi-Quest International, Inc. 2004). Storm-induced silt-ins frequently left the canal unusable (Slawsky 2004), which led the president of a shipping company to admit in 1998 that "the last two years have been disastrous for the MR-GO" (Duffy 1998).

While a series of severe storms in the late 1990s slowed business, it accelerated the effort to close the canal. Critics focused on the flood danger of the built environment. Pete Savoye from the St. Bernard Sportsmen League explained the urgency: "I was an environmentalist. Now, I am more concerned with more important things - our lives and homes" (2004). In 2002, two retired engineers from St. Bernard, Ed Doody and John Laguens, formed the Coalition to Close the MR-GO Now. The Coalition partnered with the Holy Cross Neighborhood Association in the Lower Ninth Ward and energized public skepticism toward the MR-GO (see www.ccmrgo.org/). A 2004 survey documented the organizational success of the community. Over two-thirds of respondents in St. Bernard agreed the MR-GO increased the likelihood of flooding, 
and only $23 \%$ of respondents believed the MR-GO should remain open to all traffic (Blakely and Bazile 2004).

In the face of declining traffic on the MR-GO, higher maintenance costs and surging public outcry, the Krewe de Growth showed a willingness to close the MR-GO-but not until the half billion dollar lock project could be completed in 2017 (Bazile 2004). Port officials deployed the discourse of entrepreneurial structuralism in their defense by insisting that they could not "isolate a handful of businesses" that still relied on the waterway (Schleifstein 2004: 10) and asserting their "responsibility to maintain our economy and deep-draft traffic" (Bazile 2004: 1). To the opposition, the lock project did not represent an acceptable alternative, for the flood danger had become too great (Doody and Laguens 2004). A columnist for the New Orleans Times Picayune captured the severity of the dilemma: "Let us hope a hurricane does not produce a surge along the Mr. Go before we have figured out how to close it down" (Gill 2004: Metro, 7). A St. Bernard Councilman showed equal foresight: "If we have to wait until the lock is built, we may not be here" (Balize 2004: 1). Unfortunately, Katrina confirmed the worst local fears and prophesies of community destruction.

\section{Conclusion}

This socio-historical study examined the inter-relationships between the built environment and social inequality. Contrary to the claims of some previous scholars (e.g. Miron 1992), this work conclusively demonstrates that the New Orleans "social aristocracy" actively engaged in local growth politics throughout the $20^{\text {th }}$ century. It reveals how Big Easy Elites shaped the urban landscape in their own interests through their control of the Dock Board. The Krewe de Growth exhibited the power to convert its ideological claims contained in the discourse of modernization and entrepreneurial structuralism into concrete alterations to the New Orleans landscape. In the cases of the Industrial Canal and Mississippi River-Gulf Outlet, it expropriated land for new infrastructure and obtained public funding to completely revamp the built environment of St. Bernard Parish and the Lower Ninth Ward. 
While much of the post-Katrina analysis in the popular media rightly looks at race and poverty, this research uncovered another element of the city's social inequality in its government structure. It reveals the historical link between the unaccountable power of a non-elected board and the transportation infrastructure that destroyed two communities in the New Orleans area. The social costs and economic benefits of the built environment were unevenly distributed before the most recent hurricane. Residents in the Lower Ninth Ward and St. Bernard experienced immediate disruptions to their lives; and construction in the 1920s and 1960s displaced selected families. Hurricane Katrina exacerbated what had always been an uneven arrangement when it displaced more than 80,000 people who lived in these communities.

If anything, Hurricane Katrina made visible a more general contradiction of capitalist urban development when it runs unchecked by democratic institutions. The Dock Board was created so business elites could regulate these tendencies without substantive public interference. The community protests reviewed in the final section constituted a social contradiction to the unaccountable power of this non-elected board. Neighborhood groups and civic organizations asserted their right to have a voice in the decision-making that formed the built environment in which they lived and worked. They confronted the longstanding inequality in New Orleans: the established privilege of the social aristocracy, who shaped their neighborhoods while living elsewhere in the city. Frequently in conflicts between businesses and neighborhood groups, the concerns of residents are dismissed as "not in my backyard" ideology, or "NIMBYISM." However, promises of "jobs and progress" and ultimatums of "prosper or perish" broadcasted by growth coalitions receive equal scrutiny all too rarely.

To close, I want to make clear that I do not interpret Hurricane Katrina and the experience of New Orleans as evidence that all economic growth is unsustainable and inexorably approaches environmental catastrophe. However, the tragedy and its historical precursors do confirm the need for meaningful democratic oversight of the unaccountable growth coalitions active in every American community. 


\section{Notes}

${ }^{1}$ The Army Corps of Engineers had long insisted the levees could withstand a category 3 hurricane. While Katrina made landfall as a strong category 4 to the west of the city, New Orleans only experienced a category 2 storm.

${ }^{2}$ I use the term "built environment" to refer to the socially produced urban space that encompasses the totality of a city's physical structure, including housing, industry, retail, cultural institutions and transportation and social infrastructure (Harvey 1976).

${ }^{3}$ State and County Quickfacts U.S. Census Bureau: http:// quickfacts.census.gov/gdf/states/22/22087.html).

${ }^{4}$ Missouri State Census Data Center, Population Trends Report, 19601995: http://leap.ulm.edy/POPHS/190years.txt.

${ }^{5}$ State and County Quickfacts U.S. Census Bureau: http:// quickfacts.census.gov/gdf/states/22/22087.html.

${ }^{6}$ State and County Quickfacts U.S. Census Bureau: http:// quickfacts.census.gov/gdf/states/22/22087.html).

${ }^{7}$ Greater New Orleans Data Center: http://www.gnocdc.org/orleans/ $8 / 22 /$ snapshot.html. However, a greater proportion of residents moved to Jefferson Parish or St. Tammany Parish. These parishes are also more prosperous than both Orleans and St. Bernard.

${ }^{8}$ Center For Business and Economic Research, University of Louisiana at Monroe.

${ }^{9}$ Considering the widespread agreement regarding the influence of local elites, it is surprising that this group in general and non-elected boards remain under studied in the urban literature on New Orleans (for exceptions, see Coltan 2005 and Kellman 2003). Some scholars examining the post-war decline of the city postulate an elite disengagement with local politics following the 1960s. For example, Glassman (1978) suggests that the isolationist culture of New Orleans' elite, centered on Mardi Gras and the exclusive "krewes" which organize parades and balls, turned corporate investment away from the city and left a perpetual leadership vacuum. Miron (1992) claims that their distrust of government involvement in the economy and preservationist values stymied development. Mumprey and Moomau (1984) also argue that "a southern bias against government interference in private concerns" discouraged city leaders from pursuing critical federal funds such as offered by Urban Renewal (91). The argument here, on the other hand, suggests that elites were not too withdrawn but wield unaccountable power, which allowed for the poor land use decisions. 
${ }^{10}$ In capitalism, production occurs for profit, and capitalists must recycle a portion of their profits (i.e. capital) back into production. The recycling constitutes the accumulation process, which is a structural necessity of the economic system. Accumulation also gives rise to a number of contradictory tendencies that threaten profitability and growth, such as working class resistance, over accumulation of capital, or the destruction of the environment (O'Connor 1994).

${ }^{11}$ Roweis and Scott (1981: 127-130) identify three forms of state intervention in urban land use and the production of space. First, it utilizes fiscal mechanisms such as property taxes and rent control, as well as subsidies and tax abatements. Second, the state regulates land use through zoning, planning and other restrictive devices. Finally, the state directly invests in the built environment through infrastructural projects and other forms of social spending (e.g. public housing).

${ }^{12}$ For an historical analysis of non-elected boards see Teastrom's The Unheralded Triumph. For theoretical discussion on their antidemocratic implications see Turner's Liberal Democracy 3.0.

${ }^{13}$ Port business encompasses a variety of economic actors. A sample of the enterprises includes steamship and barge companies, customs brokers, freight forwarders, stevedores, railroad lines, ship yards, truck lines, and industrial manufacturing. Numerous financial institutions directly invest in this industry, and myriad commodity producers rely on its services (e.g. agriculture, coal, petrochemical products, steel, etc.).

${ }^{14}$ The New Orleans Clearing House is a consortium of four banks. Later acts added two new organizations - New Orleans International House and Jefferson Parish Council - and recognized the name change of the Association of Commerce to Chamber of Commerce to the New Orleans Area. Additionally, one board member was required to reside in Jefferson Parish. Since construction of the MR-GO it changed again. Now the Board has seven members (one from St. Bernard) with several more nominating organizations.

${ }^{15}$ A socio-economic analysis of Board memberships from 1896 to 1972 by Schill (1974) illustrates the overwhelming representation of New Orleans business elites. Over $97 \%$ of commissioners were executives or partners of their own business. After 1940, 86.1\% were officers or directors of one or more of the nominating organizations.

${ }^{16} \mathrm{~A}$ second change to social relation involved the federal government but would only become in subsequent years. The canal opened a door for federal participation in port operations. Later, the Army Corps of Engineers leased out the locks and forebay to make a portion of the canal a federally controlled waterway (Corps of Engineers U.S. Army and Maritime 
Administration of U.S. Department of Commerce 1947). The Army Corps of Engineers would later join the ranks of the Krewe de Growth. In total, this action strengthened the Big Easy Elites' clutch over land use practices.

${ }^{17}$ In more recent years, the width of the MR-GO has expanded to 2,500 feet in some areas as a result of erosion, and the draft of many ocean vessels has outgrown its depth.

${ }^{18}$ The iconography in the campaign for the "sea-way" channel printed in the Dock Board's Port Record consistently gendered the port associating the project with strength and male virility.

${ }^{19}$ House Document 245 from the $82^{\text {nd }}$ Congress, $1^{\text {st }}$ session consists of the collection of reports completed by the Army Corps of Engineers that was transmitted to the House Committee on Public Works with a favorable recommendation by the Chief of Engineers. One noteworthy development in this aspect of the process was the reduction of channel depth made by the Chief Engineer from 40 feet to 36 feet (House Document $245,1951)$.

${ }^{20}$ I selected the term to make the irony salient that businessmen - the mythical, pioneer individualists and "men of character"- underplay, if not outright deny, their own agency in the proposals.

${ }^{21}$ The Congress defines feasibility to mean that "the benefits, to whomsoever they may accrue, are in excess of the estimate cost" (quoted in Eckstein 1961:2).

\section{References}

Army Corps of Engineers 1951. Mississippi River-GulfOutlet. 82 Congress. First Session. House Document 245.

Army Corps of Engineers and United States Maritime Commission 1947. The Port of New Orleans, Louisiana. Port Series No. 20. Revised ed. Washington D.C.

- 1958.The Port of New Orleans, Louisiana. Port Series No. 20. Revised. Washington DC.

Atkinson, Paul 1969. Our Port: Prosper or Perish. New Orleans LA: The Times Picayune Company.

Bankston, Carl L. and Stephen J Caldon 2002. A Troubled Dream: The Promise and Failure of School Desegregation in Louisiana. Nashville TN: Vanderbilt University

Barkekov, Timothy, Robin Boyle and Daniel Rich 1989. Privatism and Urban Policy in Britain and the United States. Oxford: Oxford University Press. 
Bazile, Karen Turni 2004. April 30. "Parish gains ally in MR-GO battle." New Orleans Times Picayune: P.1.

2004. May 5. "Port chief urged to help close MR-GO." New Orleans Times Picayune: P. Metro 1.

Blakely, Amy and Karen Turni Bazile. 2004. May 29. "Survey: Residents want MR-GO closed.” New Orleans Times Picayune: P. Metro 1.

Board of Commissioners for the Port of New Orleans. 1926. Port Handbook of New Orleans. New Orleans LA.

- 1940. Port of New Orleans: An Answer to the past and current criticism of its Policy and Administration. New Orleans LA.

- 1943, August Port Of New Orleans Record,. New Orleans LA. 1947, January. Port Of New Orleans Record. New Orleans LA . 1947. Second Supplemental Brief in Support of the Proposed Tidewater Ship Channel. New Orleans LA. LA.

Bolding, G.A. 1969. “The New Orleans Seaway Movement." Louisiana History 10(1): 49-60.

Brown, Matt. 2005, October, 24. "Katrina may mean MR-GO has to go" New Orleans Time Picayune: P.1.

Caffey, R.H. and B. Leblanc 2002. Closing the Mississippi River-Gulf Outlet. National Sea Grant Library. No. LSU-G-02-004.

Campanella, Richard. 1998. Time and Place in New Orleans: Past Geographies in the Present Day. Gretna, LA: Pelican Publishing.

Chai, C. Y. W. 1977."Who Rules New Orleans? A Study of Community Power Structure." Louisiana Business Survey: 2-11.

Colten, Craig E. 2005. An Unnatural Metropolis: Wrestingling New Orleans from Nature. Baton Rouge: Louisiana State University Press: Baton Rouge.

Cronon, William 1983. Changes in the Land. Toronto: McGrall-Hill.

Darce, Keith 1999. August 20. "Port to sell land for new lock." New Orleans Times Picayune, P.C1.

Domhoff, G. William. 1998. Who Rules American: Power and Politics in the Year 2000. Santa Cruz CA: University of California Press.

Doody, Ed and John P. Languens. 2004 June 17. Personal interview with author.

Duffy, George E. 1999. October 26. "Gulf Outlet Vital to City, State Economy." New Orleans Times Picayune: P. B4.

Eckstein, O. 1961. Water-Resource Development: The Economics of Project Evaluation. Cambridge, MA: Harvard University Press. 
Fortune Magazine. 1948 November. "The Great New Orleans Steal” Pp.102103.

Gabe, Thomas, Gene Falk, Maggie McCarty and Virginia W. Mason. 2005. Hurricane Katrina: Sociodemographic Characteristics of Impacted Areas. CSR Report for Congress.

Gill, James. 2004. February 29. "MRGO, washout." New Orleans Times Picayune: P7.

Glassman, James K. 1978 July. "New Orleans: I have seen the Future, and it's Houston." Atlantic Monthly: 10-18.

Gotham, Kevin F. 2002. Race, Real Estate and Uneven Development. Albany NY: SUNY Press.

- 2005. "Tourism Gentrification: The Case of the New Orleans' Vieux Carre (French Quarter).” Urban Studies 43(7): 1099-1121.

Gottdiener, Mark 1985. The Social Production of Space. Austin TX: University of Texas Press.

Grunwald, Micheal. 2005. Semptember 8. "Money flowed to Questionable Projects."

Washington Post: A1. Gulf South Research Institute (1975) An Economic Impact Appraisal Mississippi River-Gulf Outlet New Lock and Connecting Channels Lower Site (Violet), St. Bernard. Baton Rouge LA.

Harvey, David. 1976. "Labor, Capital, and Class Struggle around the Built Environment." Politics and Society 6: 265-293.

-1981. "The Urban Process under Capitalism: a Framework for Analysis." In Michael J. Dear and Allen John Scott. eds., Urbanization and Urban Planning in Capitalist Society. London: Methuen.

-1996. Justice, Nature \& the Geography of Difference. New York: Basil Books

Helling, Amy and Theodore H. Poister 2000. "U.S. Maritime Ports: Trends, Policy

Implication, and Research Needs." Economic Development Quarterly 14(3): 300-315.

Hirsh, Arnold R. 1992. "Race Politics in Modern New Orleans: The Mayoralty of Dutch Morial" American Studies 35:461-484.

Judd, Dennis R. and Todd Swanstrom 1994. City Politics: Private Power and Public Policy. New York: Harper Collins College Publishers.

Juhn, D.S. .1967. Growth and Changing Composition of International Trade Through the port of New Orleans. New Orleans LA: Louisiana State University in New Orleans.

Kelman, Ari. 2003. A River and Its City. Berkeley, CA: University of California Press 
Kenyon, James B. (1970) "Elements of Inter-Port Competition in the United States." Economic Geography 46(1): 1-24.

Koeferl, John. 1999. May 27. "Area Residents Firmly Against Lock Project." New Orleans Times Picayune: P.B6.

Lauria, Mickey and M.J. Soll. 1996. "Communicative Action, Power, and

Misinformation in a Site Selection Process." Journal of Planning and Research 15: 199-211.

Ledoux, Amy. 1993. October 11. "MR-GO: Economic Blessing or Ecological

Disaster." New Orleans City Business: A19-20,22.

Lefebvre, Henri.1991. The Production of Space. Cambrige MA: Blackwell. Levine, Marc V. 1989. "The Politics of Partnership: Urban Redevelopment

Since 1945." In Gregory D. Squires ed. Unequal Partnerships: The Political Economy of Urban Redevelopment in Postwar America.

New Brunswick NY: Rutgers University Press.

Lewis, Pierce F. 2003. New Orleans: The Making of an Urban Landscape. Santa Fe, NM: University of Virginia Press.

Logan, John R. and Harvey L. Molotch 1987. Urban Fortunes: The Political Economy of Place. Berkeley CA: University of California. Louisiana Legislature. 1944 May 29. Concurrent Resolution No. 18.

Martinez, R.J. 1955. The Story of the River Front. New Orleans LA: Industries Publishing Agency.

Marshall, Bob. 2006 January 29. "For Centuries, Canals kept New Orleans dry. Most people never dreamed they would become Mother Nature's Instrument of Destruction." New Orleans Times Picayune: P1.

Mazmanian, Daniel, A. and J. Nienaber 1979. Can Organizations Change? Washington D.C.: Brookings Institute:

McQuaid, John and Mark Schleifstein. 2002 June 24. "The Big One.” New Orleans Time Picayune: A1,7-10.

Miron, Louis F. 1992. "Corporate Ideology and the Politics of Entrepreneurialism in New Orleans. Antipode 24(4): 262-288.

Multi-Quest International, Inc. 2004. Economic Impact and Opportunities: The Mississippi River Gulf Outlet. A reported prepared for the St. Bernard Parish Council.

Mumphrey, Anthony J. and Pamela H. Moomau. 1984. "New Orleans: An Island in the Sunbelt." Public Administration Quarterly 8: 91-111. National Wildlife Federation and Taxpayer for Commonsense. 2003. Crossroads: Congress, the Corps of Engineers and the Future of America's Water Resources. http//www.nwf.org/greeningcorps.

New Orleans Official Daily Court Record. 1945 March 20. "A New Economic Impulse of Great Value to the MI VAL." University of New Orleans Special Collections: NO Inventory-Association of 
Commerce Collection. Scrapbook. 1921-1923, 1925,1927,1933,19431946.

1943 September 7. "New Orleans Looks Ahead" University of

New Orleans Special Collections: NO Inventory - Association of Commerce Collection. Scrapbook. 1921-1923, 1925,1927,1933,19431946.

1945 June 13. "What the Tidewater Ship Channel will Mean for to the Valley" Jun 13, 1945 . University of New Orleans Special Collections: NO Inventory - Association of Commerce Collection. Scrapbook. 1921-1923, 1925,1927,1933,1943-1946.

New Orleans States Item 1923 November 20. "Industrial Canal and Inner Harbor" p. 15.

- 1943 July 27. (special insert) p. 21

New Orleans Times Picayune. '1943 August 6. "Vital Need of Tidewater Channel for Port Outlined: Orleans Leaders Endorse Seaway at Hearing." p1-2.

_. 1955 April. "Ship Canal MVA No.1 Objective.” Pp.1,6

— 1955 December 7. "Seaway to Gulf Project Lauded." Pp.1, 3.

— 1956 December 12. 1956 "N.O. Bock Board to Acquire Land."

P.7.

- 1957 December 10. "The Digging Starts." P.15

.1957 December 11."Terrific Charge of Dynamite Begins Tidewater Channel" Pp.1, 3

Port." P.1

1963 September 30. "Seaway Fight Covers Years." Pp. 1,6.

. 2001 February 24. "Industrial Canal lock project opposed." P.

B5. Perry, Huey L. and Alfred Stokes. 1987. "Politics and Power in the

Sunbelt: Mayor

Morial of New Orleans.” Pp. 222-255 In Michael B. Preston, Lenneal J.

Henderson Jr. and Paul L. Puryear eds., The New Black Politics. New

York: Longman.

O'Connoer, James. 1971. The Fiscal Crisis of the State. New York: St. Martins Press.

1994. “Is Sustainable Capitalism Possible?” In Martin O'Connor ed. Is Capitalism Sustainable? New York: Gulford Press.

Rosenberg, D. 1988. New Orleans Dockworkers: Race, Labor, Unionism: 1892-1923. State University of New York: New York.

Rousefell, G.A. 1964. Reconstruction Study of the Fisheries of the Estuarine Areas 
Traversed by the Mississippi River-Gulf Outlet. Fisheries Bulletin: 63(2):673-693.

Roweis, Shoukry T. and Allen J. Scott. 1981. "The Urban Land Question." In Michael J. Dear and Allen John Scott. eds., Urbanization and Urban Planning in Capitalist Society. London: Methuen.

Savoye, Pete 2004. April 4. Personal interview with author.

Schill D.F. 1974. The Board of Commissioners of the Port of New Orleans: A Recruitment and Administrative Analysis with Three Case Studies of Board Decision-Making. A Dissertation. University of New Orleans. Louisiana Collection.

Schleifstein, Mark 2005 August 27 "Corps start chemical testing in canal: Funding woes, protest delay lock project." New Orleans Time Picayune: P.1

_. 2004 July 17. "Steps Toward Restoration.” New Orleans Times Picayune: A1,A10

2004 July 28. "MR-GO armor plan blasted at hearing." New Orleans Times Picayune: B1,B2

Shallat, Todd 2000. "In the Wake of Hurricane Betsy" In Craig E. Colten, ed. Transforming New Orleans and Its Environs. Pittsburg: University of Pittsburg.

Smith, Neil. 1990. Uneven Development: Nature, Capital and the Production of Space. Cambridge, MA: Basil Books.

Smith, Michael Peter and Dennis R. Judd 1981. "American Cities: The Production of Ideology." In Michael J. Dear and Allen John Scott. eds., Urbanization and Urban Planning in Capitalist Society. London: Methuen.

Smith, Michael Peter and Marlene Keller. 1984. ““Managed Growth” and the Politics of Uneven Development in New Orleans." In Fainstein et. al. eds. Restructuring the City: The Political Economy of Urban Redevelopment. New York: Longman.

Squires, Gregory D. 1989. "Public-Private Partnerships: Who Gets What and Why." In Gregory D. Squires ed. Unequal Partnerships: The Political Economy of Urban Redevelopment in Postwar America. New Brunswick NY: Rutgers UniversityPress.

Steigman, E.S. 1971. A Thumbnail Sketch of the Port of New Orleans and the Board of Commissioners for the Port of New Orleans. New Orleans LA.

Teaford, Jon C. 1984. The Unheralded Triumph: City Government in America. Baltimore: John Hopkins University Press.

Thibodeaux, W.C. 1951. The New Orleans-Houston Port Rivalry. A Dissertation.University of New Orleans. Louisiana Collection. 
Torres, Manuel 2005 October 19, "Bernard blames MR-GO for flood: Parish weigh suing Corps of Engineers" New Orleans Times Picayune: P.6. Turner, Octavia 2000 May 2. "ACORN plans to keep fighting Industrial Canal Lock" New Orleans Times Picayune: P.B4.

Turner, Stephen P. 2003. Liberal Democracy 3.0. London: Sage Publications.

Turni, Karen. 2001 February 7. "St. Bernard taks stand on Lock Project." New Orleans Times Picayune: P1.

Warner, Coleman 2000 April 21. "Bottleneck." New Orleans Times Picayune: P1.

Whelan, Robert K. Alma H. Young and Mickey Lauria 1994. "Urban Regimes and Racial Politics in New Orleans." Journal of Urban Affairs 16(1): 1-21.

Willems-Braun, B. 1997. "Buried Epistemologies: The Politics of Nature in (Post)colonial British Columbia." Annals of the Association of American Geographers 87(1): 3-31.

Weigend, Guido G. 1958. "Some Elements in the Study of Port Geography" Geographic Review 48(2): 185-200.

Whoriskey, Peter. 2005 October, 17, "Risk Estimate Led to Few Flood Policies." Washington Post. 2005: A01.

Young, Alma H. and Robert K. Whelan 1993. "Strategic Planning for the Port of New Orleans." In Peter B. Meyer ed., Comparative Studies in Local Economic Development. Westport CN: Greenwood Press. 